\title{
Kant and Dependency Relations: Kant on the State's Right to Redistribute Resources to Protect the Rights of Dependents*
}

\author{
HELGA VARDEN University of Toronto
}

\begin{abstract}
Contrary to much Kant interpretation, this article argues that Kant's moral philosophy, including his account of charity, is irrelevant to justifying the state's right to redistribute material resources to secure the rights of dependents (the poor, children, and the impaired). The article also rejects the popular view that Kant either does not or cannot justify anything remotely similar to the liberal welfare state. A closer look at Kant's account of dependency relations in "The Doctrine of Right" reveals an argumentative structure sufficient for a public institutional protection of dependents and evidence that Kant identifies concerns of economic justice as lying at the heart of the state's legitimacy.
\end{abstract}

RÉSUMÉ: Au contraire de ce qu'affirment bon nombre d'interprétations, le présent article soutient que la philosophie morale de Kant et ses explications sur la charité ne justifient pas adéquatement le droit de l'État à redistribuer les biens matériels afin de garantir les droits des citoyens non autonomes (les pauvres, les enfants, les handicapés). Cet article rejette aussi l'idée largement diffusée que Kant ne justifie pas ou est incapable de justifier quoi que ce soit s'approchant même vaguement d'un État providence de type libéral. Une lecture attentive aux explications sur les relations de dépendance que l'on trouve dans «La doctrine du droit» dévoile une structure argumentative à même de défendre une institution publique vouée à la protection des citoyens non autonomes et fournit des preuves à l'effet que Kant voit la question de la justice économique comme un élément central de la légitimité de l'État.

*Winner of the 2005 Dialogue Student Essay Prize.

Dialogue XLV (2006), 257-84

(c) 2006 Canadian Philosophical Association/Association canadienne de philosophie 


\section{Introduction $^{1}$}

This article challenges much of contemporary Kant-interpretation by arguing that Kant can and indeed does justify the state's right to redistribute resources to protect the rights of dependents. Contrary to most Kantinterpretation, I also argue that Kant's moral philosophy, including his account of charity, is irrelevant to this justification. I will argue that if we take a closer look at Kant's account of dependency relations as found in "The Doctrine of Right" we have all that is needed to justify the state's right to coercively redistribute resources as required to make these relations rightful.

According to Kant's political philosophy as presented in the "Doctrine of Right," a dependency relation is a relation between private persons, where the freedom of one person is subjected to the choices of others. If a person's freedom is subjected to another person's arbitrary choice, then the involved relation is wrongful. Kant's claim is that it is impossible to avoid this type of wrongdoing in the state of nature even if all persons act on the best of moral intentions. To use Arthur Ripstein's phrase, justice is not a "remedial virtue" for Kant, meaning that the state is seen as necessary even if we assume that no person ever wants to act viciously and that the material resources available in the world are plentiful (Ripstein 2004, p. 3). ${ }^{3}$ Consequently, we will see that not only is the state a necessary precondition for justice even under ideal conditions, but also that the state's right to redistribute resources follows from the way in which the state enables rightful private relations. On my interpretation, Kant establishes an argumentative framework, according to which concerns of economic justice are identified as lying at the heart of a state's legitimacy.

Many Kant scholars will be surprised by my claim that Kant's political philosophy justifies anything remotely similar to the contemporary welfare state. In fact, very few Kant interpreters and neo-Kantian philosophers think that Kant in the "Doctrine of Right" is at all concerned with issues of economic justice. In one way or another, most Kantians agree with Wolfgang Kersting in his claim that

Kant's legal and political equality lacks all economic implications and social commitments; it cannot be used to justify the welfare state and to legitimize welfare state programmes of redistribution. The promotion of social equality and the increase of economic justice is not considered as a legally necessary political aim by Kant's political philosophy. (Kersting 1992a, p. 153) ${ }^{4}$

Kersting also thinks it is impossible to justify anything remotely similar to the liberal welfare state on the basis of Kant's position (ibid., p. 164, n.7). ${ }^{5}$ Of course, many contemporary neo-Kantians disagree with Kersting's claim, though they agree that in order to develop more egalitarian Kant- 
ian theories of justice it is necessary to depart from Kant's actual theory. How Kant's position needs to be modified in order to incorporate concerns of economic justice depends on what aspects of his theory one takes to preclude attention to these concerns. Some, such as Onora O'Neill, Allan D. Rosen, and John Rawls, identify the main problem as rooted in Kant's account of charity. What makes Kant's theory insensitive to concerns of economic justice, they argue, is that Kant's principles of justice seem unresponsive to considerations of need. These positions also agree that a solution cannot be found within Kant's "Doctrine of Right." ${ }^{6}$ Others, such as Sarah W. Holtman and Paul Guyer, believe that by, reformulating Kant's position as found in the "Doctrine of Right," we can find room for considerations of economic justice. Finally, Hannah Arendt and Alexander Kaufman agree with John Rawls that we must find a way of making Kant's principles of justice apply to the human condition of material need, but they argue that the solution is to be found in Kant's Critique of Judgement, rather than in the "Doctrine of Right."7

I am in agreement with those Kantians, such as Rawls and Arendt, who argue that a primary aim for Kant's theory is that of applying principles of justice to the empirical world. I also agree with those, such as O'Neill, who emphasize that problems relating to dependency require public institutional solutions. Where I disagree with all of these positions, though, is that, in their move away from Kant's actual position, they incorporate elements inconsistent with the fundamental principle of a Kantian theory, namely, individuals' rights to freedom. Moreover, I disagree that Kant does not provide the necessary elements to justify the state's right to redistribute material resources. Indeed, I argue that the "Doctrine of Right" includes everything required to justify what can loosely be referred to as a liberal welfare state.

I emphasize here how Kant's defence of the state's right to redistribute resources to protect the rights of dependents follows from the foundation of any liberal theory of justice, namely, the individual's right to freedom. First, I give a brief introduction to Kant's conception of political freedom. Once Kant's conception of political freedom is clear, we see why the contemporary Kantian theories mentioned above must be rejected. Next, I explain how the problems of rightful acquisition entail that civil society is an enforceable precondition for justice, meaning that public institutions are required for just private relations. Understanding Kant's arguments concerning rightful acquisition of private property and domestic relations is crucial to understanding how a just state reconciles its rightful monopoly on coercion with dependents' rights to freedom. We will see that the state has the right to redistribute resources so as to protect the rights of dependents even though no individual person has the corresponding right. Furthermore, we will see why the state must posit laws establishing conditions under which all persons with the necessary capacities can work them- 
selves into full private independence. Finally, I argue that since the state has the duty to gradually transform itself into what Kant calls a "true republic," it has the right to redistribute those resources necessary to establish the institutions enabling all citizens to become active participants in public reason. From the analysis of these two aspects of Kant's position, namely, the state's reconciliation of its rightful monopoly on coercion through enabling rightful private relations and by transforming itself into a true republic, there arises a Kantian conception of the just state that comes close to what we today loosely refer to as a liberal welfare state.

\section{Kant's Conception of Political Freedom}

Kant's legal and political philosophy begins with the assumption that human interactions must be reconcilable with each person's only innate right, namely, her right to freedom, or what Kant also calls "the right of humanity in our own person" (6:240). The right to freedom is the individual's right to "independence from being constrained by another's choice [Willkür] . . . insofar as it [the individual's use of freedom] can coexist with the freedom of every other in accordance with a universal law" (6:237). The innate right to freedom is captured in Kant's Universal Principle of Right. It states: "[a]ny action is right if it can coexist with everyone's freedom in accordance with a universal law, or if on its maxim the freedom of choice of each can coexist with everyone's freedom in accordance with a universal law" (6:230f, cf. 8:289f.). The conception of political freedom implied in the innate right to freedom and the Universal Principle of Right is a relational conception of external freedom. According to this relational conception, interacting persons' actions are restricted only by universal laws, meaning that their actions are restricted symmetrically and noncontingently. With this conception of political freedom in hand, we will see that it is problematic to argue, as the various positions do, that Kant's theory is consistent with making charity enforceable (O'Neill, Rosen), with making it responsive to need (Guyer, Rawls), or with turning into a capability approach (Kaufman).

In order to understand how the innate right to freedom and the Universal Principle of Right lead to a relational conception of political freedom and to see why these contemporary Kantian theories give up something distinctive and important to Kant's theory, it is helpful to traverse the conceptual territory. The innate right to freedom is the individual's right to independence from being constrained by the arbitrary choices of others. Issues of justice or political freedom arise only in relation to uses of freedom that possibly constrain or affect others, namely, what Kant calls external freedom, which is the freedom we exercise when we set and pursue ends of our own. Political freedom, then, or the freedom protected by the innate right to freedom, is not to be seen as unrestricted external freedom. Rather political freedom protects us from coercion, or from other 
persons' subjecting our external freedom to their arbitrary choices. Political freedom is a relation between interacting persons in the exercise of their external freedom (6:231).

To say that Kant's conception of political freedom is explicitly relational in nature is to say that right or political freedom is concerned "only with the external and indeed practical relation of one person to another, insofar as their actions, as deeds, can have (direct or indirect) influence on each other" (6:230). If my external actions do not affect another, for example, if I live alone on a desolate island or if I sit at my desk and think really hard, no issues of justice or political freedom arise (6:261; cf. 27:523). In these cases I do, of course, choose my own ends or exercise freedom. Indeed, when I think really hard and when I am alone on the desert island my actions are unrestricted by any other person. However, since in these two cases there is no external interaction between others and myself, there is no political freedom. Political freedom therefore is a lawful (not unbounded) relation between individuals' external freedom. Persons who are free in the political sense are independent of one another in that their ability to set and pursue their own ends is not subject to each other's arbitrary choices. To have one's freedom subject to another's arbitrary choice means that another person decides which ends one can pursue with one's own means. It means that one's ability to set and pursue ends is no longer under one's own control. Conversely, the person who subjects another's external freedom to his arbitrary choice treats the subjected person's external freedom as a part of his own means. A person considers another person as a mere means if he forces him to pursue certain ends, if he coercively deprives him of his rightful possessions, or if he uses another's rightful possessions to pursue his own ends without having first obtained consent from the owner.

There is no conceptual space between right (political freedom) and authorization to use coercion (hindrance of freedom). Kant says that "[r]ight and authorization to use coercion . . . mean one and the same thing" (6:232). Political freedom is independence from coercion or freedom from other persons' hindrances of one's external freedom. In other words, each person has a right to hinder anyone who tries to stop her from exercising her external freedom rightfully. This entails that rightful coercion is the "hindering of a hindrance to freedom" (6:231; 8:292f.). Therefore, a person has a right to hinder someone who attempts to hinder her freedom, which is to say that right and authorization to use coercion amount to the same thing.

The innate right to freedom protects our right to independence with regard to how we set our ends as long as these choices respect other persons' right to do the same. A politically free person is not required to use his means to set any particular ends for himself or required to act from any particular motivation. It may at this point be useful to contrast Kant's 
conception of political freedom with his conception of ethical freedom. First, ethical freedom considers the motive or incentive behind an action crucial to determining the morality of the action. That is, in Kant's ethical theory a moral action is distinguished from an immoral action in part by the motive behind the act. The moral person acts from the motive of duty and not, for example, out of prudence. ${ }^{8}$ In political freedom, by contrast, motive plays no role in determining the rightfulness of actions, since the incentive does not affect the question of whether one person's actions constrain another person's freedom. ${ }^{9}$

Second, the ethically free person has a duty to act on certain subjective maxims, such as those involving the perfection of her natural and intellectual capacities and responding to others' needs by assisting them in their pursuit of happiness (6:386). However, as we saw above, the innate right to freedom does not require a person to set any particular ends for himself. Kant argues that right "does not signify the relation of one's choice to the mere wish (hence also to the mere need) of the other, as in actions of beneficence and callousness, but only a relation to the other's choice" (6:230). In contrast to moral relations, rightful relations are not about how we respond to other persons' needs, but only how we respond to their choices or to their right to use their means to pursue their own ends. ${ }^{10}$ Rightful (political) relations are concerned with choices only, and therefore we must distinguish between what we can choose and what we desire, want, or wish. If I do not have the means required to obtain what I desire, then I am merely wishing I could do something. In contrast, if I have the ability (the required means) to fulfill a desire, I can take purposive action in accordance with it or I can choose (Willkür) to fulfill my desire (6:213). In this way, the means (things) I have as my own mark the limits of my ability to choose rightfully and thus set the limits for the ways in which I can use external freedom rightfully. Anything beyond what I have means to obtain can only be pursued rightfully if others, say, out of beneficence or generosity, want to assist me; in this case they are morally responding to my need. That someone has a moral obligation to respond to my need does not mean that she has a political obligation to respond to it. ${ }^{11}$

It is crucial to realize that rightful relations are distinct from moral relations in that they require us only to respect each others' choices, meaning that we must respect one another's right to choose which (non-aggressive) ends to pursue with one's means. It might be helpful to consider this point from a different angle. The innate right to freedom protects each individual's right to set and pursue her own ends (rather than those of another). Particular ends are contingent in that they flow from an individual's subjective choices. Therefore, coercion can never involve enforcing some particular, contingent end without also denying some person's innate right to freedom (6:230; cf. 27:511f., 527, 539f.). Political freedom is to interact in such a way that our freedom is never coercively subjected to one another's 
arbitrary choices, but only to reciprocal non-contingent restrictions (6:232). Any enforcement of a particular end will involve giving some particular person a right to determine which ends another should pursue with his means and this necessarily amounts to depriving him of his right to freedom.

In light of the above, we can now delineate which restrictions upon actions are consistent with political freedom, namely, which are restricted by universal law and which are not. We have established that rightful restrictions upon a person's external freedom cannot involve forcing him to use his means to pursue contingent ends. Such use of coercion subjects his external freedom to someone else's arbitrary choice. Moreover, to be consistent with political freedom it follows that restrictions must be symmetrical or reciprocal. Symmetrical or reciprocal restrictions are those that restrict similar actions in the same way. Asymmetrical or non-reciprocal restrictions are irreconcilable with all persons having equal rights to freedom because they involve permitting one of the interacting persons to exercise his external freedom in a way that asymmetrically constrains others in their exercise of freedom. Laws that restrict rightfully are universal: therefore they cannot involve forcing a particular person to use his means to pursue particular, contingent ends and they must restrict persons symmetrically or reciprocally.

It follows from the above that the theories proposed by Guyer, Kaufman, O'Neill, Rawls, and Rosen fundamentally conflict with that of Kant in that they all defend what he considers to be contingent restrictions upon persons' actions. Presupposing particular needs (Guyer, Kaufman, Rawls) when applying the principles of justice or suggesting that state institutions can make the charity right enforceable (O'Neill, Rosen) results in contingent restrictions on our actions. Such contingent restrictions entail that some particular persons' freedom is subjected to the arbitrary choices of others rather than restricted only by principles of freedom. For this reason I believe that these contemporary interpretations are inconsistent with Kant's own position, and therefore they are fundamentally flawed.

\section{The Impossibility of Justice in the State of Nature}

We have seen that on Kant's position justice or political freedom is a condition under which the external choices of all interacting persons are restricted by universal laws reconcilable with each person's right to freedom. Such a condition obtains only if the interacting persons' external freedom is restricted symmetrically or reciprocally as well as noncontingently. Therefore, rightful use of coercion is coercion that restricts symmetrically and non-contingently. Wrongful use of coercion is arbitrary use of coercion whereby one person subjects another person's external freedom to his arbitrary choice rather than to universal law. Kant 
argues that coercion is rightful only within civil society and that justice is impossible in the state of nature even if all persons act on the best of intentions. But why is this so? That is, why is it impossible to subject one's uses of external freedom to universal law or to avoid wrongful uses of external freedom (wrongful coercion) in the state of nature? There are two reasons: first, it is impossible to provide rightful assurance of rightful possessions in the state of nature (6:245-57), and, second, it is impossible to acquire external things rightfully in this condition (6:258-307). Without rightful assurance and rightful acquisition, political freedom is impossible. For our purposes here it is unnecessary to consider the argument concerning rightful assurance, so I focus only on the issue of rightful acquisition.

\section{Acquisition of Rightful Possessions: The Problem of Indeterminacy and Enforcement}

The innate right to freedom requires that my external freedom is subjected only to my arbitrary choice and otherwise only restricted by universal law. In order to have external freedom it must also be possible for me to possess means with which I can set and pursue my own ends. Kant calls such means "objects of my choice." Objects of my choice are any means I not only "have the physical power to use" (6:246), but that also constitute part of my ability to set and pursue ends. Since rightful possession beyond my body is not innate, we must explain how affirmative acts can give rise to an acquired right in an external object of choice (6:237). Kant argues that there are three different kinds of rightful possession, namely, those involved in private property, contract relations, and rightful domestic relations. ${ }^{12}$ For our purposes here, we need only focus on the problems that arise in the spheres of private property and domestic relations in the state of nature.

Since Kant has a relational conception of right, we must understand original acquisition as primarily a relation between persons - and not as a relation between the acquiring person and the thing acquired (6:258f.). Because Kant's conception is relational in this way, it aims to capture how rightful acquisition entails obligations on behalf of everyone to respect the rightful acquisition of an object by some particular individual (6:260). At the same time, of course, unilateral acquisition is not relational and cannot give rise to rightful obligations. The task for Kant then is to reconcile unilateral acquisition with the relational requirement of right. But this reconciliation is problematic because our individual choices, and hence the actual boundaries we draw between what we consider to be our own and what belongs to others, are entirely contingent from the point of view of freedom. An individual cannot justify his claim that his particular boundary of ownership is objectively better than any other proposed boundary. Therefore, there arises a problem of indeterminacy with respect to determining the boundaries of rightful acquisition (6:266f.). This prob- 
lem of indeterminacy arises not because we cannot know what the boundary of a possession is, but because there is no single non-contingent (objective) standard by appeal to which an individual can justify his boundary over anyone else's. Therefore, any unilaterally drawn boundary cannot give rise to other persons' obligations not to interfere with a particular acquisition because such a unilaterally drawn boundary is necessarily arbitrary and does not restrict in ways reconcilable with the Universal Principle of Right. So, in the state of nature, we cannot appeal to the Universal Principle of Right to solve the problem of indeterminacy because it is the application of the principle itself that is indeterminatethere is no single correct way to apply the principle. That is, it is impossible for individuals in the state of nature to apply the Universal Principle of Right and thereby rightfully determine the quantity and quality of any single appropriation of goods, because such an application of the principle will be unilateral and arbitrary and therefore irreconcilable with itself (8:289f.). For these reasons, private property in the full sense of the word is impossible in the state of nature. ${ }^{13}$

The only way to apply the Universal Principle of Right in a way that is reconcilable with itself must go through the postulate of a general will or a public authority. As I have argued, the problem of indeterminacy with respect to determining rightful rules for original acquisition requires a solution that cannot be conceptually reduced to the particular private will of each person. Only by establishing a public authority, or "the lawgiving of the will of all thought as united a priori" (6:268), to specify and enforce standards for appropriation of property, can the problem of indeterminacy be overcome and rightful relations among acquiring persons be achieved. With respect to any pair of interacting individuals, the general will is the will of each one of them united as one will. A public will is not tied to any particular private interest, so its restrictions are not contingent, and therefore they are reconcilable with each person's right to freedom. This is because the public authority has the appropriate standing with respect to all the interacting individuals. It can rightfully posit and enforce laws since it is the will of all as opposed to the will of any particular one. In this way, civil society is necessary to make private property rights determinate and enforceable.

\section{Why Civil Society Is an Enforceable Precondition for Domestic Right}

Similarly, it is also impossible in the state of nature to make domestic relations - what Kant calls status relations-rightful. A status relation is a relation between persons in which one person has the right to "make arrangements" affecting another person's private life (6:259). Since these relationships involve legally enforceable claims to the private life of another person, Kant describes these rights as concerning "what is mine or yours domestically" and also as the "most personal" of all rights 
(6:277). It is a right a person has to possess another person "as a thing." This means that the possessor has a right to share a domestic sphere with the possessed person and to set private ends for her. Obviously, since it is a person who is possessed, the use of the one possessed can only be "as $a$ person" $(6: 277)$ and not as a thing, meaning that one can only set moral ends for the other person. ${ }^{14}$

As pointed out by Barbara Herman (2002) and Arthur Ripstein (2004), the first problem that arises in status relations is that consent cannot do the legitimating work it does in contracts. This is not because status relations include relations between caregivers and care-receivers who cannot assume responsibility for themselves. The reason is that status relations involve rights to persons rather than rights against persons. This means that the possessor presumably has a right to set an indeterminate number of (moral) ends within the private or domestic sphere of another person. The problem is that a person cannot (consensually or not) enter into a relation where her own person is no longer subject to her own choice. This is slavery. And the open-ended, personal character of status relations appears to entail exactly this. As we will see, this problem is solved by giving persons involved in status relations reciprocal, open-ended rights to one another's person.

The second problem arising in status relations that cannot be solved in the state of nature concerns the enforcement of claims to persons. It is this problem that leads Kant to argue that we can acquire status (or possession) with regard to another person only "by law" (lege) (6:276). The reason it is impossible to conceive of rightful, enforceable claims against one another's person in the state of nature is that within the conceptual framework of this condition, there is no person outside of a particular status relation who is authorized to intervene in it. Hence, the judgement about whether the parties are acting in one another's best interests, or within "moral boundaries," becomes the judgement of the stronger person in the relationship. Without a public authority to act as a "civil guardian" over the parties involved in status relations, it is impossible to ensure that the relationship is rightful, rather than one of abuse and wrongdoing.

Both problems, of establishing reciprocity and enforceable claims, arise in each of the three types of status relations. Status relations arise when parents obtain children, when husbands obtain wives, and when families obtain servants (6:277; cf. 27:642). Kant meets the first challenge of justifying such acquisitions of persons by arguing that the possessed person must have rights reciprocal to those of the possessor. Such reciprocal possession is necessary to reconcile the possession of a person with the innate right of humanity. Reciprocity is secured in these relationships by also giving children, wives, and servants legally enforceable claims against the person of their parents, husbands, and employer families. Nevertheless, Kant argues this is insufficient to make the three types of status relations 
rightful in the state of nature. The reason for this is common to all three status relations. A more careful consideration of the parent-child relation will elicit the problems in a way that allows for a more abbreviated discussion of the other two relations.

On Kant's view, children are persons and therefore possess the innate right of humanity (6:280ff.). Yet at the same time children cannot set and pursue their own ends in a morally responsible manner. They require assistance from others to learn how to do this. Since parents unilaterally decide to bring children into the world, they are responsible for taking care of them until the children can take care of themselves. ${ }^{15}$ Parents have a duty to provide their children with care-understood as conditions under which they can develop their pragmatic, theoretical, and practical capacities sufficiently to become persons capable of living independent lives (6:281). To reconcile parents' rights to set ends for their children with the children's right of humanity, parents cannot make their children means only to their own ends. To use children in such a way conflicts with the child's innate right to freedom, because it both involves using the child as a mere means, and it inhibits the child's ability to learn to set and pursue her own ends independently. Indeed, parents must set ends for their children, but only those ends that further the child's ability to become a morally and legally responsible person. ${ }^{16}$ Therefore, parents cannot rightfully set immoral ends for their children, such as self-destructive ends. Parents who fail to provide their children with such conditions of care wrong their children.

The problem that remains in the state of nature is that no one except the parents of the child is authorized to act on behalf of the child and, consequently, children's rights are unprotected in the state of nature. No one particular individual, including the child, has the appropriate standing in relation to the child that authorizes him to evaluate the parents' ability to act on the child's behalf or to intervene or replace the parents in cases of severe mistreatment of the children. Consequently, though a parent wrongs the child, the child has no remedy, since neither the child nor any other adult person (non-parent) has the standing that allows rightful overruling of the parents' decision. Insofar as we are in the state of nature, rightful relations between parents and their children cannot be realized because the evaluation of whether a particular parent is acting in the child's best interests rests solely with that parent. The possible wrongdoer becomes his own judge. This is why there is something inherently abusive about this kind of status relation in the state of nature. ${ }^{17}$ The only way to ensure that these relations are rightful is to establish a public authority comprising the general will to protect the rights of children. Only a public authority can have the proper standing to evaluate the rightfulness of particular parent-child relations and to engage in rightful enforcement. 
Kant argues that, as status relations, the relationship between husbands and wives and between families and their servants are characterized by the same formal problem as the relationship between parents and their children. ${ }^{18}$ As in the case with children and their parents, one person entitled to represent another gives rise to the problem of securing protection against wrongdoing between these persons in the state of nature. Wives and servants, on the other hand, are morally and legally responsible persons, and their consent is necessary to establish rightful status relations with them. From this point onwards, however, the argument is quite similar: because these relations are status relations, the legal claims involved include the right of one person to set private ends or restrict the private sphere of another. Hence, the first step involved in making these kinds of relations rightful, Kant argues, must be to make the legal claims reciprocal. Husbands and wives, as well as servants and their families, must have legal claims to one another's person.

According to Kant, however, justice is not realized simply by giving wives and servants reciprocal legal claims. In the state of nature, there exist only self-contained, private, domestic spheres, and no one outside of such a private sphere has the appropriate standing to evaluate the rightfulness of the relations within it. Therefore, there is no rightful use of coercion with regard to domestic relations. To establish domestic right there must be established a person with the appropriate standing to adjudicate disputes and enforce those judgements amongst adults sharing a domestic sphere. Only a public authority can have this standing, since only a public person can be the will of all, and hence have the right to make enforceable decisions concerning both parties. Finally, as in parent-child relations, it is insufficient to designate a private third person to adjudicate and enforce domestic right involving adults. No private individual can fulfill this function, since she does not enjoy the requisite standing to enforce rights. Moreover, consent cannot do the work of establishing appropriate standing, because consent cannot give rise to enforceable rights. A public authority is therefore necessary to have enforceable domestic rights amongst adult persons. Furthermore, to reconcile its interventions with each person's innate right to freedom, the way in which it interferes must be symmetrical and in accordance with posited, non-arbitrary laws of domestic right.

We have seen that only a public authority can overcome the problems of indeterminacy and enforcement in a way consistent with each person's right to freedom. Kant therefore concludes his discussion of private right in the first part of the "Doctrine of Right" by arguing that we must accept a second postulate, namely, that of public right (6:306-307). Public right is not a remedy against any "inconveniences" of the state of nature, but is a precondition of justice whose necessity is not demonstrated by appeal to our animal nature or to the lack of worldly resources. Kantian circum- 
stances of justice are not those of Locke or Hume. Rather than viewing the state as prudentially necessary to establish justice, Kant considers it a condition for the possibility of political freedom. He argues that civil society is strictly necessary to establish justices regardless of how well disposed people are towards one another or how plentiful the resources (6:312). Until what belongs to each is determined by a public authority, rightful relations have not been established. Therefore, Kant's non-consensual conception of political obligations, or the duty to enter civil society, follows from the right of humanity and the duty not to wrong anyone. It has nothing to do with prudence or our tendency to act viciously. ${ }^{19}$

At this point it is clear that we have a strict duty to enter civil society in order to ensure rightful relations amongst private individuals. I now turn to the question of what a political power must look like if it is to count as a civil authority. Kant argues that in order for the political power to establish those rightful relations between individuals that were impossible in the state of nature, it must represent the general will by constituting itself as the will of each person born within its jurisdiction (4:294f.; 6:317, 330). This means that the public authority must posit and enforce laws in such a way that they secure each citizen's freedom, equality, and independence (6:314; 8:290). Moreover, Kant argues, this cannot mean only that the public authority must set itself up with a monopoly on uses of coercion; it must also reconcile its monopoly with each individual's right to freedom. This is something possible only if the public authority establishes a certain institutional structure, without which a particular political power is not a legitimate civil authority. And without legitimacy no political obligations exist. In addition, Kant argues that, although the existence of political obligations does not depend on it, the state must also transform itself into a "true republic" or one in which the people govern themselves through active participation in public reason. Since my concern is dependency relations, I will focus only on the state's duty to establish institutional protection for the poor and its right and duty to transform itself into a true republic.

\section{How Civil Society (Public Right) Enables Rightful Dependency Relations}

We find Kant's explicit discussion of the state's institutional protection of the poor in Section C of public right (6:325-28). However, I will argue that we should consider relevant three other aspects of Kant's theory when we develop his full conception of rightful dependency relations: first, Kant's comments that citizens must find themselves within a framework of positive law within which they can work themselves into active citizenship; second, his view that the state is necessary to make domestic relations rightful, and, finally, his argument that the state must evolve into a true republic. When all these considerations are brought into play, we see that 
Kant's conception of the just state may just as easily be described as a liberal welfare state. ${ }^{20}$

Let us start by unpacking Section C of public right. In order to understand this section correctly, it is important to remember that for Kant the state is an enforceable and necessary precondition for property broadly understood, and it is an enforceable precondition for private property relations, contractual relations, and domestic relations. Because a public authority necessarily has a monopoly on coercion, a specific problem arises in that the state creates a dependency relation between itself and its subjects that it must make rightful. By this I mean that individuals no longer have the right to use coercion to set and pursue ends of their own since all uses of coercion are now under the auspices of the state. The question then is how to make the dependency relation rightful between the state and those who have no means and no right to use coercion to pursue their ends. What the state must do is ensure that its monopoly on coercion is not such that any one of its subjects is deprived of his innate right to freedom. That is, the state must ensure that no individual's external freedom is subject to another's arbitrary choices. Kant's claim is that this can be done only by means of an institutional guarantee of unconditional poverty relief.

To reconcile its rightful monopoly on coercion with the rights of the poor, the state must ensure that no person finds herself without any means whatsoever with which to pursue ends. To be free in the external sense requires the possession of external things, and therefore unconditional poverty relief is necessary if the state is to fulfill its role, namely, to provide conditions under which persons can exercise their innate right to freedom. Without such unconditional poverty relief the poor have no freedom, since they have nothing, and any access to means goes through some other private person's consent either to hire them or provide them with charity. Essentially, then, because the poor have no means, their right to set and pursue ends is subject to the arbitrary choices of those who have means. Consequently, if the state upholds its monopoly on coercion, the state must also step in to ensure that the poor do not find themselves in such a condition. This is why Kant maintains that the state has a right and a duty to tax the rich in order to provide unconditional relief for the poor, even though he also says that no individual private person has the right to coerce another to give her resources to the poor. ${ }^{21}$

With respect to children and care-receivers in general, the state must establish those institutions necessary to ensure that all children and those not able to care for themselves are provided with capable caregivers. On the one hand, the state has the right to redistribute the necessary resources to increase parents' ability to care for their children, say, by providing them with child-care education or by giving them financial support. On the other hand, the state must also establish institutions that solve prob- 
lems of abusive, deceased, or absent parents. This may involve supporting and supervising what Kant calls private "foundling homes" (6:325f.) or what we understand in contemporary terms as private caretaking institutions for children. In these ways, the state ensures that all poor persons, including children and those otherwise unable to care for themselves, are provided with poverty relief.

Following from the argument justifying the redistribution of resources to provide relief for the poor is the radical claim that a society having persons with no means, and access to means only through charity or other persons' private decisions to employ them, is one in which there is no political freedom. This is because the state is not providing conditions under which all persons can exercise their innate right to freedom. Without a guarantee of unconditional poverty relief, the state's monopoly on coercion is irreconcilable with the poor person's right to freedom, which means that the state has not fulfilled the requirement that it provides conditions under which all persons can exercise their rights to freedom. Remember that political freedom consists in rightful relations between all persons, which means that the denial of any person's right to freedom entails also the denial of political freedom for all. Therefore, without an institutional guarantee of unconditional poverty relief, the state is not legitimate and political obligations do not exist. It is important to clarify that the claim is not that the state, in order to be legitimate, must have an extensive welfare system. The claim is only that the state must take institutional steps whereby it makes means available to those who have none. ${ }^{22}$

The above suffices - indeed, on its own - to explain why issues of economic justice are central to Kant's conception of the just state. Nevertheless, as mentioned above, I believe that there are three additional considerations of economic justice underwriting this claim. I will consider, first, Kant's argument that all citizens must be able to work themselves into what he calls "an active condition." Kant explains in the sections on public right that the just state is compatible with the existence of passive citizens, namely, persons who "have to be under the direction or protection of other individuals, and so do not possess civil independence" (6:315). By this he means that the mere existence of persons who are not fully independent of other private individuals is not in itself a sign of injustice. His examples include children, women, and apprentices-all persons who are in a passive condition in that they do not have the means required to enjoy full private independence. Kant, however, emphasizes that conditions under which passive citizens can work themselves into an active condition must be secured:

For from their being able to demand that all others treat them in accordance with laws of natural freedom and equality as passive parts of the state, it does not follow that they also have the right to manage the state itself as active members of 


\section{Dialogue}

it, the right to organize it or to cooperate for introducing certain laws . . . [but the] positive laws [must] not be contrary to the natural laws of freedom and the equality of everyone in the people corresponding to this freedom, namely that anyone can work his way up from this passive condition to an active one. (6:315, $8: 295 f.)^{23}$

Granted, in this passage, Kant is talking about active citizenship in a democracy. Nevertheless, civil society need not be a democracy in order for the same point to apply. That is, Kant is defending the view that, despite the fact that the empirical requirements of active citizenship can change depending on whether civil society is, say, a democracy or an aristocracy, no posited law can make it impossible for persons to work themselves from a passive condition into an active one. In other words, no person can be denied through law the right to become an active citizen.

There are two plausible ways to interpret this passage as suggesting that Kant intends the possibility of obtaining active citizenship to be a minimal condition on the state's legitimacy. We can understand Kant to be saying that the minimal condition consists in the requirement that a legitimate state cannot posit laws according to which some particular person is denied the right, either by the state or by some private person, to work herself out of her passive condition. On this rather weak interpretation, no one can be explicitly and legally denied the right to choose to pursue active citizenship. For example, women, or any social or ethnic group, cannot be denied the right to appropriate private property. More generally, the state cannot posit laws that allow discrimination on the basis of race, gender, or ethnicity with regard to whatever means are required to obtain active citizenship. On this weaker interpretation, to secure conditions under which a person can move from a passive to an active condition just means that the state has a negative duty in the sense that it must not legislate in a way that explicitly denies a person the possibility of obtaining active citizenship.

On the stronger interpretation, to secure conditions under which persons can move from a passive to an active condition means that the state has a positive duty to ensure that the totality of legislation is such that all persons actually can work themselves into an active condition. For example, on this reading, the positive duty might consist in legislation that ensures that no one person must accept work under conditions incompatible with obtaining an active condition. The state reconciles its monopoly on uses of coercion only if it ensures that no one finds herself in a situation where the only choices available to her promise nothing but a perpetual passive condition. This means that the state ensures that the poor can work themselves into independent persons economically, financially, and with respect to land ownership. The state ensures that the poor are not denied participation in these systems due to a lack of means and that all 
persons can work themselves into full private independence within these systems. I believe that this stronger interpretation of Kant's position is the interpretation that is most fully reconcilable with his most fundamental assumption, namely, each person's right to freedom.

We have seen that the state's legitimacy requires unconditional poverty relief and conditions under which passive citizens can work themselves into an active condition. Still, as noted above, I think that Kant's position also supports the additional claim that, unless the state provides institutional guarantees of domestic relations, it is not legitimate. Although the claim has no direct textual support, I think it follows from Kant's position that in order for domestic relations to be rightful there must be a public authority with standing to the relationship to provide the means through which a distinction can be drawn between wrongful and rightful relations. If the state establishes a monopoly on coercion that does not distinguish between rightful and wrongful uses of coercion in the domestic sphere, then it fails to reconcile its coercion with each person's innate right to freedom. Not to do so is to uphold a monopoly on coercion that is irreconcilable with a person's right not to be subject to other persons' arbitrary choices. Therefore, the state must establish a public institution with the appropriate standing to determine rightful and wrongful uses of coercion in domestic relations. Since the reasoning is analogous with regard to the domestic right of married couples and families who have servants, it is not necessary to investigate the details of these arguments. Instead we simply note that the state must set up institutions as necessary to secure the rightfulness of all domestic relations. For servants, this may require public institutions responsible for ensuring that servants find themselves under decent working conditions, whereas for married couples, it may require the provision of institutional solutions to persons experiencing marital problems. It is impossible a priori to specify exactly how the state fulfills its role as a civil guardian: the only thing we can say a priori is that it must set up institutions by which it aims to enable rightful domestic relations.

We have seen that the legitimate state must provide unconditional poverty relief in the form of public institutions to protect a person's right to have means or be externally free. I have also argued that there are two additional related conditions on state legitimacy that follow from Kant's account: first, a legitimate state must provide conditions under which no citizen is either denied the legal right or actually cannot work herself from a passive to an active condition; and, second, the state must establish institutions to secure domestic rights. These arguments lead to the conclusion that concerns of economic justice are essential to the state's legitimacy: without the state's redistribution of resources to protect the rights of dependents with respect to poverty relief, institutional solutions to passive citizenship, and domestic conflicts, the state is not legitimate and no political obligations exist. ${ }^{24}$ In contrast to the claims of Kersting and others, I 
conclude that Kant actually identifies issues of dependency, including economic justice, as determining the existence of political obligations. ${ }^{25}$

Perhaps the most surprising implication of these arguments is that, contrary to most Kantians, Kant does not consider the rights of the state and the rights of individuals as identical. Indeed, if we read Kant's theory as identifying the coercive rights of individuals with those of the state, we mask the ways in which Kant's account actually identifies issues of economic justice as lying at the heart of a state's legitimacy. The right to redistribute resources is beyond the rights of individuals, and yet institutional redistribution of resources is strictly required for state legitimacy. In addition, on the assumption that the state's rights are equivalent to individuals' rights, the redistribution of resources is in violation of individuals' rights to freedom. In other words, since any private redistribution will conflict with the individual's innate right to freedom, contemporary Kantians encounter problems when trying to explain why the state has the right to coercively redistribute resources even though no individual enjoys the same right. And yet, explaining the state's right to coercively redistribute resources is necessary to finding a convincing Kantian solution to the problem of the protection of the rights of vulnerable dependents in civil society. I have suggested that, in fact, in the "Doctrine of Right," Kant provides the solution by explaining why we must let go of the assumption that the state's rights cannot outstrip the rights of individuals.

In these final sections, let me turn to the state's right and duty to provide conditions in which citizens can become active participants in public reason. In my view, the state must have the right and duty to enable participation in public reason because it has the right and duty to transform itself into a "true republic" in which citizens are "the sovereign itself": citizens in a "true republic" are self-legislators through active participation in the public reason of the sovereign (6:341). But because political obligations do not depend on the state transforming itself into a true republic, this transformation is not required in order for the state to be politically legitimate or for political obligations to arise. Nevertheless, this does not undermine the general argument that the ideal republican organizational form requires that the people govern themselves through public reason, and the state can become this kind of a republic only if it makes possible that people can become capable participants in public reason. So, although the state need not be a "true republic" in order for political obligations to exist, it must strive towards providing conditions under which persons can participate in public reason.

We can distinguish between two parts of public reason, namely, public discussion and public offices or professional positions, both of which are constitutive of a public coercive authority. ${ }^{26}$ In order to partake in both these aspects of public reason, citizens must have the requisite knowledge and qualifications. First, one cannot engage in public discussion of public 
matters without a certain level of knowledge of public affairs. Therefore, the state has the right and duty to provide all persons with the education necessary to participate in public discussion. Second, one cannot govern oneself through public reason if one does not have the requisite ability to hold public positions and professional offices. That is, at least in Western societies today, public power is exercised through public administrative and political offices and through professional titles, such as academic professors, chartered accountants, lawyers, physicians, and engineers. These offices are typically entrusted with the daily application of the state's laws and policies, and they perform important advisory functions to the government, legislators, and the Supreme Court. Hence, if "the people" are to govern themselves, they must be able to hold such public positions and professional offices, and the state must (gradually) transform itself into a system that provides institutional protection - through education - of the right to obtain this ability. Providing educational opportunities for all citizens with the requisite capacities is a prerequisite for a state organized according to the republican ideal, since education is the means through which people can obtain the abilities required to participate in self-legislation through public reason. ${ }^{27}$

\section{Conclusion}

The aim of this article has been to defend an alternative to the standard Kantian interpretation of dependency relations, namely, one that does not make any appeal to the imperfect duty of charity or to Kant's moral philosophy, but stays strictly within his conception of justice as we find it in the "Doctrine of Right." We have seen that the strength of Kant's account of dependency relations is in part its ability to capture essential, enforceable aspects of these relations, and in part to demonstrate that justice requires a public institutional framework if interactions between independent persons and dependants are to be rightful. We have seen that the just state must establish institutions that provide unconditional poverty relief and institutions necessary to ensure domestic right. In addition, the state must posit laws that ensure that the poor can work themselves into full independence from other private persons. Thus, in a truly civil society, passive citizens, or citizens who lack full private independence, necessarily include only children and the mentally incapacitated. All others can enjoy full private independence from one another. In its roles of guarantor of external freedom and civil guardian, the state's rights and duties to protect its citizens' rights to freedom exceed the rights of individuals. Furthermore, we saw that, though the existence of political obligations does not depend upon this, the state has the right and duty to transform itself into a true republic in which the people govern themselves through public reason. Finally, we concluded that establishing this civil, legal framework to regulate our interactions constitutes an aspect of realizing ourselves as 
free beings: it is not a remedial response to our typical tendency to act viciously. And a fortuitous advantage of this interpretation is that it is possible to explain justice in terms of freedom without appealing to some particular conception of needs or some particular view of morality or religion. Instead, its claims are grounded on the implications of our having an innate right to freedom understood as an innate right to set and pursue ends independently of the arbitrary choices of others.

\section{Notes}

1 I want to thank Lorraine Bruce, Phil Clark, Svein Eng, Thomas E. Hill, Jr., Nibal K. Lubbad, Amy Mullin, Arnt Myrstad, Jonathan Peterson, Arthur Ripstein, Gopal Sreenivasan, Chloë Taylor, Sergio Tenenbaum, and Shelley Weinberg for their generous help and support in writing this article. I am especially grateful to Arthur Ripstein for having so big-heartedly shared his knowledge of Kant with me throughout the writing process. Special gratitude is also owed Arnt Myrstad and Shelley Weinberg for seemingly endless discussions of the content and presentation of this article. Earlier versions were presented at the University of Tromsø (May 2004), the Midwest Study Group of the North American Kant Society (NAKS) at Purdue University (October 2004), the Canadian Philosophical Association's Congress (CPAC) at the University of Western Ontario (May 2005), and at the International Kant Conference in São Paulo (September 2005). I would like to thank these audiences and my commentator at the CPAC, Louis-Philippe Hodgeson, for insightful questions and comments. Finally, I would like to thank Arne Robertsen and Unni Pedersen for having shared with me their extensive knowledge of dependency relations and for having been so very patient as I made every mistake during my learning process.

2 The references to this and all Kant's works in this article are to the Prussian Academy pagination. The Prussian Academy pagination of Kant's works are found in the Kant references at the end of this article. I have used the translations as given there.

3 Other Kantians who argue in line with this assumption include Ottfried Höffe (1994, p. 183), Sarah Williams Holtman (2002, pp. 216f.), Bernd Ludwig (2002, pp. 161ff.), and Ernest J. Weinrib (1992, p. 17).

4 For similar interpretations of Kant's "Doctrine of Right," see Gregor (1963, pp. 36f.), Höffe (1994, pp. 184f.), Murphy (1994, pp. 144-46), O’Neill (2000, p. 65), Rosen (1993, p. 197), and Williams (1983, pp. 196ff.).

5 This position appears somewhat modified in Kersting (1992b, pp. 356ff.).

6 Allen D. Rosen argues that the main problem with The Metaphysics of Morals is that Kant is his own "worst interpreter" (Rosen 1993, p. 197). He argues that if Kant had been a better interpreter of himself he would (correctly) have affirmed the state's right to provide for its subjects' own conception of their happiness (ibid., pp. 173-208). O'Neill argues similarly that Kant should have argued that the state is authorized to enforce the right to charity (see, for 
example, 1989, chaps. 10 and 12; 1998, chaps. 5-7; and 2000). John Rawls argues that the problem in Kant's position is one of making the principles of justice apply in a way that makes the theory responsive to considerations of human material needs (see 1989, pp. 81-95; 1999, pp. 221-27; 2000, pp. 21734).

7 Guyer (2000) argues that the best interpretation of Kant's actual theory is close to Rawls's theory, whereas Holtman (2004) focuses on Kant's discussion of citizenship to build more room for these concerns into Kant's framework. Kaufman argues that the main problem is that Kant "offers no clear account of the relation between positive and natural law" (1999, p. 141). Like Rawls, Kaufman identifies as a main problem with Kant's theory that of applying principles of justice, and, like Arendt (1992), Kaufman goes to the Critique of Judgement to search for solutions to the problem of applying natural law or of establishing the correct relation between positive and natural law. According to Kaufman, the result is the proposal of a Kantian capability approach according to which all persons have the right to "equality of purposive agency" (1999, p. 154), meaning that all positive law must aim to ensure that all persons are provided with equal conditions for developing their capabilities for purposive agency.

8 This point is made throughout Kant's practical philosophy (cf. 4:397ff., 440f., 449; 5:20f.; and 6:379f.). This entails that even if we rightly grant to O'Neill and Rosen that it makes a difference whether it is the state or private individuals who are doing the coercing, whatever is being enforced cannot be beneficence (see below). Beneficence requires that a person voluntarily gives her money to the poor because she determines it the right thing to do. Imperfect duties require an act of self-imposition that cannot be coerced. Consequently, if we want to justify any redistribution of resources to the vulnerable in a manner conceptually consistent with Kant's position, our conceptual starting point cannot be beneficence or imperfect duties as found either in Kant's "Doctrine of Virtue" or in any other of his ethical writings.

9 See, for example, 5:71, 81; 6:213f., 219f., 225, 383; and 27:534.

10 For example, Kant argues in his lectures that simply because we are faced with need so severe that our survival is threatened, this does not give us a coercive right to another person's possessions "because the one to be despoiled already has possession, and is thereby protecting his life; the other's need can never give a coercive right" (27:517, cf. 526).

11 It is this feature of Kant's position that leads many to regard it as callous. This particular feature also seems to contradict Kant's claim later in the "Doctrine of Right" that the state can redistribute to provide poverty relief: if individuals do not have the right, how can the state have the right? At this point in the argument it is impossible to explain this, but in due course we will see Kant's theory is neither callous nor contradictory on this point.

12 According to Kant, we can have three objects of our choice since there are three relational categories of the understanding: namely, things (private- 
property right), causality (contract right), and community (domestic right) (6:259f., cf. 6:247f.). Kant's defence of this fundamental assumption is beyond the scope of this article.

13 Kant argues: "a unilateral will . . . cannot put everyone under an obligation that is in itself contingent; this requires a will that is omnilateral, that is united not contingently but a priori and therefore necessarily, and because of this is the only will that is lawgiving. For only in accordance with this principle of the will is it possible for the free choice of each to accord with the freedom of all, and therefore possible for there to be any right, and so too possible for any external object to be mine or yours" (6:263).

14 Such possession can therefore not be simply a right "to a thing [property right] . . or a right against a person [contract right]" (6:277). The former kind of possession (property right) fails to capture how it is a person who is the "external object" of possession, whereas the second kind of possession (contract right) does not give rise to rights concerning anyone's person or private life. Neither property nor contract right can therefore give us the way in which to analyze this type of right.

15 In the case of children who are permanently disabled and thus cannot develop their capacities sufficiently to become legally and morally responsible persons, it is reasonable to argue that parents remain their legal guardians for as long as they live.

16 Children can be made to do daily chores, but only as an aspect of developing their ability to be responsible persons, not as a source of cheap, domestic labour. Similarly, parents cannot allow their children to treat other individuals as mere means, as they must ensure that their children respect other persons' right of humanity, including those of the parents.

17 It is important to appreciate that it is impossible to find a private solution to the problem inherent in the parent-child relation. For example, a private solution could involve the parents appointing another private person (say, a godparent) to supervise their rearing of the child. However, this solution is insufficient not only because in this case the parents choose the judge, and therefore are still allowed arbitrarily to determine what is in their child's best interest, but also because it merely involves authorizing another person to have a say in the upbringing of the child. There is still no rightful solution to conflicts between parents and this second person, or indeed, between children and these adults. This leads us to the need for yet another person to arbitrate these conflicts, which in turn yields an infinite regress. Therefore, in the state of nature, there is no way to distinguish formally between wrongful and rightful uses of coercion between parents and their children since there is no institution in place that can make this judgement. Overcoming the problem characteristic of parent-child relations in the state of nature, then, must go via the establishment of a public person who has the appropriate standing under the law to protect the child against wrongdoing. 
18 There may be other legal relationships that also have this status structure, but addressing this question is beyond the purposes of this thesis.

19 For these reasons, I believe that many Kant interpreters are mistaken when they attribute to Kant the remedial conception of justice. For example, see Guyer (2000, pp. 236, 238f., 256, 283f.), Kaufman (1999, pp. 10f., 53, 82, 142), Murphy (1994, pp. 34, 70, 75f., 104, 107), Pogge (2002, p. 147), Westphal (2002, p. 108 - but contrast with pp. 91, 104, 109), and Williams (1983, p. 71 [cf. pp. 10f., 70f., 73, 164, 169f., 185]). Contemporary Kantian theorists typically build their theories of justice on the assumption that on the Kantian view justice is a remedial virtue. For example, Rawls wrongly assumes the Kantian circumstances of justice entail that if people were more beneficent, and resources not as scarce, "there would be no occasion for the virtue of justice" (1999, p. 110). O’Neill argues similarly (2000, p. 139).

20 Expanding on Kant's explicit account of public right is in line with how he ends the preface to the "Doctrine of Right": "Toward the end of the book I have worked less thoroughly over certain sections than might be expected in comparison with the earlier ones, partly because it seems to me that they can be easily inferred from the earlier ones and partly, too, because the later sections (dealing with public right) are currently subject to so much discussion, and still so important, that they can well justify postponing a decisive judgement for some time" (6:209).

21 For example see 6:325f., cf. 27:539. The stronger interpretation of Kant's position here, I have suggested, points out that the state must reconcile its monopoly on coercion with the rights of each, and this is why it must provide unconditional poverty relief since only in this way can it reconcile property owners' exclusive property rights with the rights of the poor.

22 In light of the above, Kant's comments about the rich and the poor in "Theory and Practice" must be interpreted with care. Kant argues that the "complete equality of men as subjects in a nation is completely consistent with the greatest inequality in the quantity and degree of possessions they have, whether these be physical or mental superiority over others, or fortuitously acquired external goods. ... Thus, the welfare of one very much depends on the will of another (that of the poor on that of the rich), one must obey (as the child its elder or the wife her husband) while the other commands, and one must serve (as laborer) while the other pays, etc. Nevertheless, as regards right (which, as the expression of the general will, can only be singular, for it concerns the form of right and not the matter or object regarding which I have rights) they are, as subjects, all equal to one another. For no one can coerce anyone else except through public law" (8:291f.). Thus, we must note two things: First, inequality as such cannot be determining for the rightfulness of property relations in a society because of the problem of indeterminacy. That is, it is impossible to quantify what is permissible inequality in a society. Second, it is also the case that the welfare of particular individuals can depend upon the choices others make in society, and, indeed, that those with fewer resources will find their 
welfare in many ways dependent upon the choices more resourceful persons make. For example, if the rich decide to spend their time investing in and developing the economy, rather than, say, travelling around the world, this will be determining for the welfare of the less resourceful. However, in my view, we should not infer from this that the poor can be absolutely subjected to the choices of the rich in the sense that there can be no institutions securing unconditional poverty relief. Though disagreements on the content of these issues cannot give rise to a right to coercively resist the public authority, the public authority must have some such institutions in place so as to make sure that the poor person's freedom (not their welfare as such) is subjected to the arbitrary choices of others.

23 We may note an interpretative puzzle that arises when Kant claims that "anyone can work his way up from his passive condition to an active one" (emphasis added). It should also be noted, however, that in the German text, "his" does not occur, but rather the gender-neutral sich - referring back to "the people" (Völk). I am grateful to Svein Eng for making me aware of this point. In "Theory and Practice" Kant argues that it is obvious without argument that being "an adult male" is a qualification for being an active citizen (8:295). There are two possible explanations for this: (a) Kant believes women lack something essential ("in their nature") that makes it impossible for them to ever become active citizens; or (b) Kant believes women lack the required independence needed to advance, since they (as a group) never enjoy the independence enjoyed by many men. The first explanation cannot be justified on Kant's account, whereas the second one can. On my view, the stronger interpretation of this second explanation considers women of Kant's time doubly disadvantaged: first, women could not work their way to independence because their freedom was subjected to the choices of their husbands or the patriarchs of their original family. This problem could be addressed simply by giving women equal rights, such as rights to education, inheritance, choice in marriage, or in employment. The second problem, a problem women shared with the servants at Kant's time, is that women typically lacked the skills required to live independent lives. This second reading obtains further support from Kant's discussion of women in "An Answer to the Question: 'What is Enlightenment?" (8:35f.). If we develop Kant's conception of women's rights from the theory presented in the "Doctrine of Right" and the "Enlightenment" article, and pay special attention to how public right concludes private right (including domestic right), I believe the result is quite different from the standard account. A main problem with the standard interpretation is that it pays too much attention to Kant's historical and anthropological writings and insufficient attention to his position as we find it in the "Doctrine of Right." For an example of an interpretation that focuses on Kant's historical and anthropological writings, see Susan Mendus (1992).

24 These additional institutions make up the difference between the (libertarian) minimal state and the liberal state, and their necessity show that the state's 
coercive authority cannot be evaluated by appeal to the individual's rights. According to my interpretation of Kant, a main problem with a libertarian interpretation of Kant's position is that it mistakenly and steadfastly assumes that the rights of the state cannot outstrip the rights of each individual. For example, Nozick famously claims that "the legitimate powers of a protective agency are merely the sum of the individual rights that its members or clients transfer to the association. No new rights and powers arise" $(1974$, p. 89). However, we have seen that this cannot be the case, since otherwise the state could uphold its monopoly on coercion without also reconciling this monopoly with the freedom of each individual. Without establishing the necessary additional institutions, the state cannot ensure that its monopoly on coercion enables a condition under which each of its citizens is placed under conditions where their freedom is not subjected to the arbitrary choices of another, but only to non-arbitrary, symmetrical restrictions.

25 My view that economic justice lies at the very heart of political obligations as presented in the "Doctrine of Right" is in disagreement with almost all contemporary Kant interpretations. For example, see Guyer (2000), Höffe (1994), Holtman (2004), Kersting (1992a, 1992b), Murphy (1994), and Williams (1983).

26 Kant refers to the former as "public" uses of reason and the latter as "private" uses of reason (8:37). The reasoning of "a certain civil post or office" to which a person was "entrusted" Kant held as being "private" since holding such public positions entails that one is pursuing the interests of the commonwealth as defined by the public reason and by the resulting laws, statutes, and decrees (8:37f.). In contrast, when engaged in what Kant calls public reason, each citizen employs her own reasoning and judgement skills, to which there should be no restrictions.

27 Kaufman affirms many of the same conclusions I defend, but he utilizes different arguments. Contrary to Kaufman, I believe Kant's position is inconsistent with a capability approach, because such an approach is inconsistent with Kant's conception of political freedom. As we saw earlier, political freedom cannot require anyone to give up his means to enable someone else to develop her abilities. Instead, I have argued that on Kant's view the rightful relation between positive and natural law follows from how the state must reconcile its monopoly on use of coercion with the freedom of each. Kaufman fails to realize this, I believe, because he starts from the assumption that justice is a remedial virtue and he therefore presupposes that the rights of the state are commensurate with the rights of individuals. 


\section{References}

Arendt, Hannah

1992 Lectures on Kant's Political Philosophy. Edited by Ronald Beiner. Chicago, IL: University of Chicago Press.

Gregor, Mary J.

1963 Laws of Freedom. Oxford: Basil Blackwell.

Guyer, Paul

2000 Kant on Freedom, Law, and Happiness. New York: Cambridge University Press.

Herman, Barbara

2002 "Could It Be Worth Thinking about Kant on Sex and Marriage?" In A Mind of One's Own. Edited by L. M. Antony and C. E. Witt. Boulder, CO: Westview Press, pp. 53-72.

Höffe, Ottfried

1994 Immanuel Kant. Translated by Marshall Farrier. Albany, NY: SUNY Press.

Holtman, Sarah Williams

2002 "Revolution, Contradiction, and Kantian Citizenship." In Kant's Metaphysics of Morals. Edited by M. Timmons. New York: Oxford University Press, pp. 209-32.

2004 "Kantian Justice and Poverty Relief." Kant-Studien, 95: 86-106.

Kant, Immanuel

1983 "On the Proverb: That May Be True in Theory, But Is of No Practical Use." Prussian Academy Pagination 8:273-313. In Perpetual Peace and Other Essays. Translated by T. Humphrey. Indianapolis, IN: Hackett, pp. 61-92.

1996a "An Answer to the Question: What Is Enlightenment?" Prussian Academy Pagination 8:33-42. In Practical Philosophy. Translated and edited by M. Gregor. New York: Cambridge University Press, pp. 11-22.

1996b Metaphysics of Morals. Prussian Academy pagination 6:203-491. Translated and edited by Mary Gregor. New York: Cambridge University Press.

1997a Groundwork of the Metaphysics of Morals. Prussian Academy Pagination 4:387-463. Translated by H. J. Paton. New York: Routledge.

1997b Critique of Practical Reason. Prussian Academy Pagination 5:1-163. Translated and edited by Mary Gregor. Cambridge: Cambridge University Press.

2001 "Notes on the Lectures of Mr. Kant on the Metaphysics of Morals." Prussian Academy pagination 27:479-732. In Lectures on Ethics. Edited by P. Heath and J. B. Schneewind. New York: Cambridge University Press, pp. 249-452. 
Kaufman, Alexander

1999 Welfare in the Kantian State. New York: Oxford University Press. Kersting, Wolfgang

1992a “Kant's Concept of the State." In Essays on Kant's Political Philosophy. Edited by H. L. Williams. Chicago, IL: University of Chicago Press, pp. 143-66.

1992b "Politics, Freedom, and Order: Kant's Political Philosophy." In The Cambridge Companion to Kant. Edited by Paul Guyer. New York: Cambridge University Press.

Ludwig, Bernd

2002 “Whence Public Right?” In Kant's Metaphysics of Morals. Edited by M. Timmons. Oxford: Oxford University Press, pp. 159-84.

Mendus, Susan

1992 “Kant: 'An Honest But Narrow-Minded Bourgeois'?” In Essays on Kant's Political Philosophy. Edited by H. L. Williams. Chicago, IL: University of Chicago Press, pp. 166-91.

Murphy, Jeffrie G.

1994 Kant: The Philosophy of Right. Macon, GA: Mercer University Press, ROSE-Edition.

Nozick, Robert

1974 Anarchy, State, and Utopia. New York: Basic Books.

O’Neill, Onora

1989 Constructions of Reason: Explorations of Kant's Practical Philosophy. New York: Cambridge University Press.

1998 Towards Justice and Virtue: A Constructive Account of Practical Reasoning. Cambridge: Cambridge University Press.

2000 Bounds of Justice. Cambridge: Cambridge University Press.

Pogge, Thomas

2002 "Is Kant's Rechtslehre a 'Comprehensive Liberalism'?" In Kant's

Metaphysics of Morals. Edited by M. Timmons. New York: Oxford University Press, pp. 133-58.

Rawls, John

1989 “Themes in Kant's Moral Philosophy.” In Kant's Transcendental Deductions. Edited by E. Förster. Stanford, CA: Stanford University Press, pp. 81-113.

1999 A Theory of Justice. Rev. ed. Cambridge, MA: Harvard University Press.

2000 Lectures in the History of Moral Philosophy. Cambridge, MA: Harvard University Press.

Ripstein, Arthur

2004 "Authority and Coercion." Philosophy and Public Affairs, 32: 2-35.

Rosen, Allen D.

1993 Kant's Theory of Justice. Ithaca, NY: Cornell University Press. 
Weinrib, Ernest J.

1992 "Law as Idea of Reason." In Essays on Kant's Political Philosophy. Edited by H. L. Williams. Chicago: University of Chicago Press, pp. 15-49.

Westphal, Kenneth

2002 “A Kantian Justification of Possession." In Kant's Metaphysics of Morals. Edited by M. Timmons. New York: Oxford University Press.

Williams, Howard L.

1983 Kant's Political Philosophy. New York: St. Martin's Press. 